\title{
THEORY OF PLANNED BEHAVIOR: ASSOCIATIONS BETWEEN INTENTION, KNOWLEDGE, AND USE OF VISUAL INSPECTION ACETIC ACID
}

\author{
Dewi Saptowati'), Ambar Mudigdo²), Bhisma Murti' \\ 1)Masters Program on Public Health, Universitas Sebelas Maret \\ 2)Faculty of Medicine, Universitas Sebelas Maret
}

\begin{abstract}
Background: Icek Ajzen's Theory of Planned Behavior (TPB) puts that intention precedes health behavior. That is, any health behavior takes place deliberately after the emergence of intervention. This study aimed to test if TPB can be used to explain the uptake of visual inspection acetic acid (VIA) screening for cervical cancer.

Subjects and Method: This was a cross sectional study conducted at 5 Community Health Centers (CHC) in Sragen, Central Java, from April to May 2018. A sample of 200 women of reproductive age were selected for this study by fixed disease sampling, composing of 50 women who used VIA and 150 women who did not use VIA. The dependent variable was use of VIA. The independent variable were intention and knowledge on VIA and cervical cancer. The data were collected by questionnaire. Data on VIA was obtained from medical record at $\mathrm{CHC}$. The data were analyzed by a multiple logistic regression.

Results: The use of VIA was associated with intention $(\mathrm{OR}=48.02 ; 95 \% \mathrm{CI}=13.66$ to $168.83 ; \mathrm{p}<0.001)$ and knowledge $(\mathrm{OR}=13.41 ; 95 \% \mathrm{CI}=2.82$ to $63.73 ; \mathrm{p}=0.001)$. Nagelkerke $\mathrm{R}^{2}=61.1 \%$.

Conclusion: The use of VIA is associated with intention and knowledge.
\end{abstract}

Keywords: intention, knowledge, visual inspection acetic acid

\section{Correspondence:}

Dewi Saptowati. Masters Program on Public Health, Universitas Sebelas Maret. Jl. Ir. Sutami No. 36A, Surakarta 57126, Central Java.

Email: dewi.saptowati@gmail.com. Mobile: +6285647506237.

The 4th International Conference on Public Health Best Western Premier Hotel, Solo, Indonesia, August 29-30, 2018 | 207 https://doi.org/10.26911/theicph.2018.03.38 